University of Nebraska - Lincoln

DigitalCommons@University of Nebraska - Lincoln

1996

\title{
Registration of 'Pronghorn' Prairie Sandreed Grass
}

\author{
Kenneth P. Vogel \\ University of Nebraska-Lincoln, kvogel1@unl.edu \\ L. C. Newell \\ Erling T. Jacobson \\ John E. Watkins \\ University of Nebraska-Lincoln \\ Patrick E. Reece \\ University of Nebraska, Scottsbluff, preece1@unl.edu
}

See next page for additional authors

Follow this and additional works at: https://digitalcommons.unl.edu/usdaarsfacpub

Vogel, Kenneth P.; Newell, L. C.; Jacobson, Erling T.; Watkins, John E.; Reece, Patrick E.; and Bauer, Dennis E., "Registration of 'Pronghorn' Prairie Sandreed Grass" (1996). Publications from USDA-ARS / UNL Faculty. 1894.

https://digitalcommons.unl.edu/usdaarsfacpub/1894

This Article is brought to you for free and open access by the U.S. Department of Agriculture: Agricultural Research Service, Lincoln, Nebraska at DigitalCommons@University of Nebraska - Lincoln. It has been accepted for inclusion in Publications from USDA-ARS / UNL Faculty by an authorized administrator of DigitalCommons@University of Nebraska - Lincoln. 


\section{Authors}

Kenneth P. Vogel, L. C. Newell, Erling T. Jacobson, John E. Watkins, Patrick E. Reece, and Dennis E. Bauer 


\section{REGISTRATION OF CULTIVARS}

\section{Registration of 'Pronghorn' Prairie Sandreed Grass}

'Pronghorn' prairie sandreed grass [Calamovilfa longifolia(Hook.) Scribn.] (Reg. no. CV-182, PI 592392) was released by the USDAARS, the Agricultural Research Division of the University of Nebraska-Lincoln, and the USDA-SCS on 5 May 1988. The cultivar was developed in cooperative research by the USDA-ARS and the University of Nebraska using plant germplasm from this cooperative program and from the Manhattan Plant Materials Center, USDA-NRCS, Manhattan, KS.

Prairie sandreed grass is a native warm-season grass found on sandy soils in the central and northern prairies of the USA. It is the most uniformly distributed and abundant grass in the Nebraska Sandhills, a 5.2-million-ha area of sandy range sites in central and northern Nebraska and adjacent areas of South Dakota (3). This region is predominantly native rangeland, but some areas have been plowed for agriculture or disturbed in other activities, such as road construction. Prairie sandreed is useful for revegetating critical sites in this region. Pronghorn was bred for superior resistance to indigenous rusts, using germplasm adapted to the Nebraska Sandhills. Rust samples collected from Pronghorn plants (and from Goshen, a check cultivar) at Mead in 1984 were identified as Puccinia amphigena Dietel by John W. McCain of the Arthur Herbarium, Department of Botany and Plant Pathology, Purdue University (personal communication).

In 1968, the USDA-SCS assembled 48 field collections of prairie sandreed grass from Nebraska, Kansas, and South Dakota and established them in unreplicated rows at the SCS Plant Materials Center at Manhattan, KS. A check cultivar, Goshen (1), was planted every 10th row. Accessions from three other Plant Materials Centers were also included in this evaluation. In 1969, this planting was evaluated for stand, vigor, and disease resistance, and the most promising accessions were identified. Original seed of the four top-ranked accessions (these were from Rock, Greeley, and Boone counties in Nebraska and Republic County in Kansas) was sent to L.C. Newell, a USDA-ARS agronomist stationed at the Nebraska Agricultural Experiment Station at Lincoln.

A space-planted evaluation and selection nursery of these accessions was established at Lincoln, NE, in 1969. An evaluation nursery of plants from collections made in Howard County, Nebraska, was also established at this time. Plants in these nurseries were evaluated for culm number, leafiness, spread by rhizomes, and rust tolerance in the fall of 1970. Superior plants were selected for polycrossing from the Boone, Greeley, and Howard populations (48, 16, and 72 plants, respectively) in the spring of 1971 . Each of the selected plants was split into six ramets, with two ramets of each plant randomly transplanted into three different isolated crossing blocks at the University of Nebraska Agricultural Research \& Development Center, Mead, NE. There were six different crossing blocks: Howard $\times$ Boone, Howard $\times$ Greeley, Howard $\times$ Howard, Greeley $\times$ Boone, Greeley $\times$ Greeley, and Boone $\times$ Boone. Plants in these isolation blocks were allowed to randomly mate via wind pollination. Progeny from Boone plants in each of the isolation blocks were established in a space-planted, unreplicated, progenyrow evaluation nursery near Mead, NE. The same procedure was followed for the Greeley and Howard populations. These nurseries contained from 1000 to more than 3000 plants. Plants were evaluated for vigor, forage production, and rust tolerance. Individual plants from the Boone, Greeley, and Howard selection nurseries $(180,147$, and 180 plants, respectively) were selected and moved into separate isolated crossing blocks. Two ramets of each selected plant were transplanted into the Greeley and Howard isolation blocks, while only one ramet of each clone was transplanted into the Boone isolation block. Seed was harvested in bulk from these isolation blocks. One thousand seedlings were grown from each of these bulk seed lots and were transplanted at random into rows to establish the breeder seed field in 1980. Foundation seed fields were established at University of Nebraska Agricultural Research $\&$ Development Center at Mead and at the USDA-NRCS Plant Materials Center, Manhattan, KS, using the Syn 1 breeder seed.

Evaluation trials of Pronghorn and Goshen were established on sandy sites at Mead, Bassett, and Scottsbluff, NE, during the period 1982 to I986. In all three environments, Pronghorn exhibited significantly $(P<0.01)$ superior leaf rust resistance in comparison with Goshen. The level of leaf rust infestation of Pronghorn is typically about one-fourth to one-half that of Goshen, the only other released cultivar (1). Pronghorn produces stands and forage yields equivalent to or superior to those of Goshen (2). Pronghorn is adapted to and recommended for use in revegetating sandy sites in the Nebraska Sandhills, adjacent areas in South Dakota, and northwestern Kansas.

Seed propagation of Pronghorn is restricted to two generations of increase from Breeder seed, one each of Foundation and Certified seed. Breeder seed (Syn 1) is maintained by the cooperative USDA-ARS and University of Nebraska grass breeding project at Lincoln, NE. Foundation seed will be maintained and distributed by the Foundation Seed Division of the University of Nebraska according to allocation policies of the University of Nebraska.

K. P. Vogel,* L. C. Newell, ERling T. Jacobson, John E. Watkins, Patrick E. REECE, AND DENNIS E. BAUER (4)

\section{References and Notes}

1. Alderson, J., and W.C. Sharp. 1994. Grass varieties in the United States. Agric. Handb. 170. U.S. Gov. Print. Office, Washington, DC.

2. Masters, R.A., K.P. Vogel, P.E. Reece, and D. Bauer. 1990. Sand blue stem and prairie sandreed establishment. J. Range Manage. 43:540-544.

3. Stubbendieck, J., J.T. Nichols, and K.K. Roberts. 1985. Nebraska range and pasture grasses. E.C. 85-170. Coop. Ext. Serv., Inst. of Agric. and Natural Resources, Univ. of Nebraska, Lincoln.

4. K.P. Vogel, USDA-ARS, 344 Keim Hall, Univ. of Nebraska, P.O. Box 830937, Lincoln, NE 68583-0937; L.C. Newell (deceased), USDA-ARS; E.T. Jacobson (retired), USDA-NRCS, 6518 Teton Dr., Lincoln, NE 68510; John Watkins, Plant Pathology Dep., Univ. of Nebraska, Lincoln, NE; P.E. Reece, Panhandle Res. \& Ext. Ctr., Univ. of Nebraska, Scottsbluff, NE 69361-4939; and D.E. Bauer, Ext. Education, Univ. of Nebraska, Ainsworth, NE 69210. Registration by CSSA. Accepted 30 Apr. 1996. *Corresponding author (Email: agro012@unlvm.unl.edu).

Published in Crop Sci. 36:1712 (1996). 